\title{
INFLUÊNCIA DA VEGETAÇÃO NO CONFORTO AMBIENTAL
}
Guilhermina Castro Silva ${ }^{1}$
Wilza Gomes Reis Lopes ${ }^{2}$
João Batista Lopes ${ }^{3}$ \\ aaCaa
}

Influence of vegetation in the environmental comfort

\begin{abstract}
Resumo
A pesquisa foi conduzida para avaliar a influência da vegetação no conforto ambiental de espaços livres urbanos centrais em cidades de clima quente, tendo como foco as Praças João Luís Ferreira e Landri Sales, na cidade de Teresina, Piauí, identificando as espécies arbóreas existentes nestas áreas e como esses aspectos são percebidos pelos usuários. Foram efetuadas medições de temperatura e de umidade relativa do ar, no período de agosto a novembro de 2008, nos horários de 9, 15 e 21 horas, em áreas com e sem vegetação. As praças João Luís Ferreira e Landri Sales apresentam uma arborização com agrupamentos heterogêneos, com espécies diferentes, como o oiti (Licania tomentosa), tendo presença marcante nestes espaços. Os usuários avaliaram as praças como muito importantes para a cidade, com destaque para a vegetação, devido à existência de aéreas de sombra e de temperaturas amenas. As áreas arborizadas das duas praças exercem efeito benéfico na melhoria das temperaturas.
\end{abstract}

Palavras-chave: Praça, Vegetação, Conforto térmico.

\begin{abstract}
This research was conducted to evaluate the influence of vegetation on the environmental comfort of open spaces in urban central of cities with warm climate, with focus in the, João Luís Ferreira Squares and Landri Sales Squares in the city of Teresina, Piauí, being identified trees in these areas and how these aspects are perceived by users. Temperature and relative humidity in the period from August to November 2008 at 9 a.m, 3 p.m. and 9 p.m., in areas with and without vegetation they were measured. The squares Joao Luís Ferreira and Landri Sales have trees with heterogeneous groupings, presenting different species, as the oiti (Licania tomentosa), having strong presence in these spaces. The users evaluated the parks as areas very important for the city, especially the vegetation, because of overhead shade and mild temperatures. The wooded areas in the two squares exert beneficial effects in improving temperatures.
\end{abstract}

Key words: Square, Vegetation, Thermal comfort.

\section{Resumen}

La investigación se llevó a cabo para evaluar la influencia de la vegetación de confort ambiental de espacios libres en las ciudades urbanas centrales el clima caliente, centrándose en las plazas João Luís Ferreira y Landri Sales, en la ciudad de Teresina, Piauí, identificar las especies de árboles en estas áreas y cómo estos aspectos son considerados por los usuarios. Allí fueron las mediciones de la temperatura y la humedad relativa del aire, en el período comprendido entre agosto y noviembre de 2008, en los tiempos de 9, 15 y 21 horas, en áreas con y sin vegetación. Los cuadrados João Luís Ferreira y Landri Sales presente una forestación con grupos heterogéneos, con diferentes especies, tales como el estado (Licania tomentosa), habiendo una notable presencia en estos espacios. Los usuarios evalúan las plazas como muy importante a la ciudad, con énfasis en la vegetación, debido a la existencia de aire de sombra y temperaturas suaves. Las zonas arboladas de las dos plazas ejercer efectos beneficiosos en la mejora de las temperaturas.

Palabras clave: Plaza, Vegetación, Confort térmico.

(1) Doutoranda no Programa de Pós-Graduação em Desenvolvimento e Meio Ambiente da Universidade Federal do Piauí. Campus Universitário Ministro Petrônio Portella, Ininga - CEP 64049-550 Teresina (PI), Brasil. Tel.: (+55 86) $3215-5525$ guilherminacastro@hotmail.com

(2) Bolsista de Produtividade do CNPq, Prof ${ }^{a}$ Dr $^{\mathrm{a}}$ do Departamento de Construção Civil e Arquitetura e do Programa de PósGraduação em Desenvolvimento e Meio Ambiente da Universidade Federal do Piauí - UFPI. Campus Universitário Ministro Petrônio Portella, Ininga, - CEP 64049-550, Teresina (PI), Brasil. Tel.: (+55 86) 3215-5725 - izalopes@uol.com.br

(3) Bolsista de Produtividade do CNPq. Prof. Dr. do Departamento de Zootecnia e do Programa de Pós-Graduação em Desenvolvimento e Meio Ambiente da Universidade Federal do Piauí. Campus Universitário da Socopo, Ininga - CEP 64049555, Teresina (PI), Brasil. Tel.: (+55 86) 3215-5750 - lopesjb@pesquisador.cnpq.br

\section{aaCaa}

Revista da ANPEGE, v. 8, n. 10, p. 67-84, ago./dez. 2012.

ISSN 1679-768 X @ 2003, Associação Nacional de Pesquisa e Pós-Graduação em Geografia. Todos os direitos reservados. 


\section{INTRODUÇÃO}

O planejamento urbano se constitui em uma importante ferramenta que tem sido usada na perspectiva de amenizar os problemas relacionados à ação humana no meio ambiente, tendo como destaque a urbanização desordenada, emissão de poluentes no ar e na água pelas indústrias, desmatamento acelerado, produção de resíduos e falta de saneamento básico que prosperaram de forma acentuada a partir da Revolução Industrial.

As transformações ambientais e ações ocorridas com a urbanização, como o excesso de emissões de gases pelos veículos, a impermeabilização do solo, o aumento de ruas asfaltadas, a verticalização das edificações urbanas e a diminuição das áreas verdes, interferem no aumento da temperatura local. O desenvolvimento e a expansão dos centros urbanos fizeram com que locais, antes vegetados, fossem transformados em áreas edificadas e pavimentadas, contribuindo para uma elevação de temperatura, causando desconforto térmico para os habitantes.

Para Mendonça e Assis (2003), o ser humano, por meio de suas ações e de seu papel no processo de ocupação, é capaz de alterar a forma urbana e ocasionar alterações do clima urbano. Segundo Spirn (1995, p. 71), "cada cidade é composta por um mosaico de microclimas, radicalmente, diferentes, os quais são criados pelos mesmos processos que operam na escala geral da cidade". A topografia, a vegetação a superfície do solo natural ou construído são fatores climáticos locais que influenciam o microclima (ALMEIDA JÚNIOR, 2005).

Vasconcellos et al. (2005, p. 2137) afirmam que

[...] esses microclimas que se originam do crescimento e do adensamento urbano são o resultado das mudanças de gabarito e da falta de afastamentos entre as edificações que criam barreiras à circulação do ar, assim como geram mudanças na iluminação natural, aumentam a poluição do ar e os níveis de ruído e alteram a umidade do ar, entre outros.

Segundo Oliveira e Mascaró (2007), nos centros urbanos, o espaço público garante maior qualidade de vida à população, por trazer benefícios ao ambiente urbano, como realização de eventos sociais, lazer, encontro ao ar livre e socialização entre as pessoas. Nas cidades, a presença das árvores em praças deixou de ser apenas um elemento decorativo para contribuir para uma melhor qualidade ambiental urbana, mitigando os efeitos negativos que a urbanização provoca.

As praças são unidades urbanísticas fundamentais para a vida urbana, contribuindo para o equilíbrio ambiental, configurando-se como locais para a prática de lazer passivo e ativo, além de servirem ao encontro e à convivência das pessoas e às atividades culturais e cívicas. Sua função é definida pelo modo como cada sociedade expressa sua vida, variando em consequência das mudanças sociais e históricas vivenciadas ao longo do tempo (LEITÃO, 2002).

Além de exercer a função de lugar de encontro e de atividades sociais, a praça, como espaço livre de construção, assume papel fundamental na mitigação dos efeitos negativos do crescimento urbano, propiciando melhoria das condições ambientais, por meio da redução de temperatura e aumento de umidade do ar, devido à presença de árvores e de outras espécies vegetais.

A arborização, além de proporcionar benefícios ao meio urbano estabelece a relação entre homem e natureza, garantindo uma melhor qualidade de vida ao homem. Mascaró e Mascaró (2002, p. 2) consideram o uso da vegetação um recurso eficiente contra o calor nas cidades tropicais úmidas, pois "além de fornecer sombreamento, permite a passagem da brisa local e absorve de maneira eficaz a radiação térmica de onda longa sobre as folhas refrescadas pela evaporação".

Importante em qualquer núcleo urbano, a vegetação se torna imprescindível em cidades de clima quente, como é o caso de Teresina, capital do Piauí, estado da região Nordeste, que é considerada como uma das cidades mais quentes do Brasil, apresentando altos valores de temperatura, em quase todo ano, principalmente nos meses de setembro a dezembro.

Dessa forma, a arborização urbana distribuída em ruas, avenidas e praças existentes na cidade proporciona áreas sombreadas que ajudam a minimizar a temperatura nos meses mais quentes, os 
quais são caracterizados pela forte irradiação solar, com temperatura apresentando média anual de $26,8^{\circ} \mathrm{C}$, com picos de $38,7^{\circ} \mathrm{C}$, tendo valor médio anual da umidade relativa do ar de $70 \%$, com oscilação que vai de $85 \%$ nos meses chuvosos a $50 \%$ nos meses mais secos e quentes (CASTELO BRANCO, 2003).

Este trabalho foi conduzido com o objetivo de estudar a qualidade ambiental de espaços livres urbanos centrais em cidades de clima quente, tendo como foco as Praças João Luís Ferreira e Landri Sales, na cidade de Teresina, Piauí. Foram identificadas as espécies arbóreas existentes nestas áreas, sua contribuição para a melhoria do conforto ambiental e como esses aspectos são percebidos pelos usuários dos espaços estudados.

\section{VEGETAÇÃO E CONFORTO AMBIENTAL}

Clima é a feição característica e permanente do tempo (estado atmosférico em um determinado momento), num lugar, em meio a suas infinitas variações (MASCARÓ, 1996). Segundo Mills (2008), relatos de estudos científicos sobre o clima urbano teve início no século XIX, com o trabalho de Luke Howard sobre os contrastes meteorológicos da cidade de Londres e seu entorno. Conhecido como pai da meteorologia, foi o primeiro a observar que as temperaturas do ar são frequentemente mais altas na cidade que na área rural à sua volta. As áreas com vegetação no espaço urbano estão associadas à qualidade de vida, além de valorizar a imagem das cidades.

Para Romero (2001), o estudo do clima compreende a formação dos fatores climáticos globais (radiação solar, latitude, altitude, ventos, massas de água e terra) com os fatores climáticos locais (topografia, superfície do solo e vegetação) e a caracterização definida pelos elementos climáticos (temperatura, umidade do ar, precipitação e movimentação do ar). A informação climática deve ser considerada em três níveis: macroclima, mesoclima e microclima.

O conforto ambiental é o "conjunto de sensações subjetivas representadas pelo conforto acústico, luminoso, visual, psicológico, espacial e térmico" (PAULA; LABAKI, 2005, p. 1424). Pode-se dizer que desde a Pré-História o homem descobriu o princípio do conforto ambiental, quando nas estações frias habitava em cavernas com aberturas orientadas na direção dos raios solares. A partir da II Guerra Mundial, com o avanço tecnológico e científico, o homem começou a desafiar as adversidades do meio ambiente e passou a construir ambientes climatizados, como uma das formas de evidenciar sua vitória sobre a natureza (RHEINGANTZ, 2001). Assim, Ayoade (2001) comenta que o homem, para atingir seus objetivos, pode por meio de suas várias atividades e ações, deliberadamente ou inadvertidamente, influenciar o clima.

No espaço urbano, a arborização influencia na qualidade de vida, por atuar no conforto ambiental, proporcionando sombra aos pedestres e veículos, melhorando a qualidade do ar, reduzindo a amplitude térmica e a insolação direta nas edificações, enfim, possibilitando a criação de um microclima mais agradável.

Dentre os vários aspectos positivos da arborização urbana, destaca-se a importância das árvores como mitigadora da poluição sonora pelos obstáculos que oferece à propagação das ondas sonoras; pelo equilíbrio da temperatura ambiente graças à sombra e evapotranspiração que realiza; pela redução da velocidade dos ventos, bem como pela redução do impacto das chuvas e a atração para a avifauna e, sobretudo, pela harmonia paisagística e ambiental do espaço urbano (GARTLAND, 2010; LIMA NETO et al., 2007; GOMES; SOARES, 2003).

Muitos dos problemas urbanos nas cidades estão relacionados ao conforto ambiental, o que tem feito crescer o número de pesquisas sobre o clima urbano e qualidade de vida (RHEINGANTZ, 2001). Com esta perspectiva, destacam-se os estudos de Mascaró (1996) e Mascaró e Mascaró (2002) que abordaram a relação do clima com a vegetação e sobre a vegetação urbana de Porto Alegre. Já, Faria e Mendes (2004) tiveram a preocupação em estabelecer metodologias, que caracterizassem a distribuição da temperatura do ar na camada intraurbana, por meio de medições móveis, comparando os dados obtidos com outros, medidos fora da área urbana, em cidades distintas, Bauru (Brasil) e 
Braga (Portugal). Nesse contexto, Fontes et al. (2005), tendo como foco medições de parâmetros ambientais, em oito praças de Bauru, estado de São Paulo, buscaram identificar a relação entre uso/ microclimas. No plano internacional, Thorsson et al. (2007) investigaram os microclimas em um parque e uma praça, na cidade de Matsudo, em Tóquio, e ainda, como estes locais públicos são apreciados e utilizados pela população.

\section{DESCRIÇÃO DA ÁREA DE ESTUDO}

A cidade de Teresina está implantada à margem direita do rio Parnaíba, sendo banhada, também, pelo rio Poti. Sua localização na proximidade da linha do Equador faz com que os raios solares a atinjam com o ângulo muito próximo a $90^{\circ}$, permitindo que a cidade receba intensa radiação e apresente temperaturas elevadas (CASTELO BRANCO, 2003).

Teresina, tendo um contingente populacional de 814.230 habitantes (IBGE, 2010), foi planejada e construída, em 1852, com a finalidade de ser a capital do Estado. No plano original (Figura 1), várias áreas foram destinadas à construção de praças, e hoje, conta em seu centro histórico, com o total de sete: Praças Marechal Deodoro da Fonseca, Rio Branco, João Luís Ferreira, Landri Sales, Pedro II, Saraiva e Praça da Liberdade (Figuras 2).
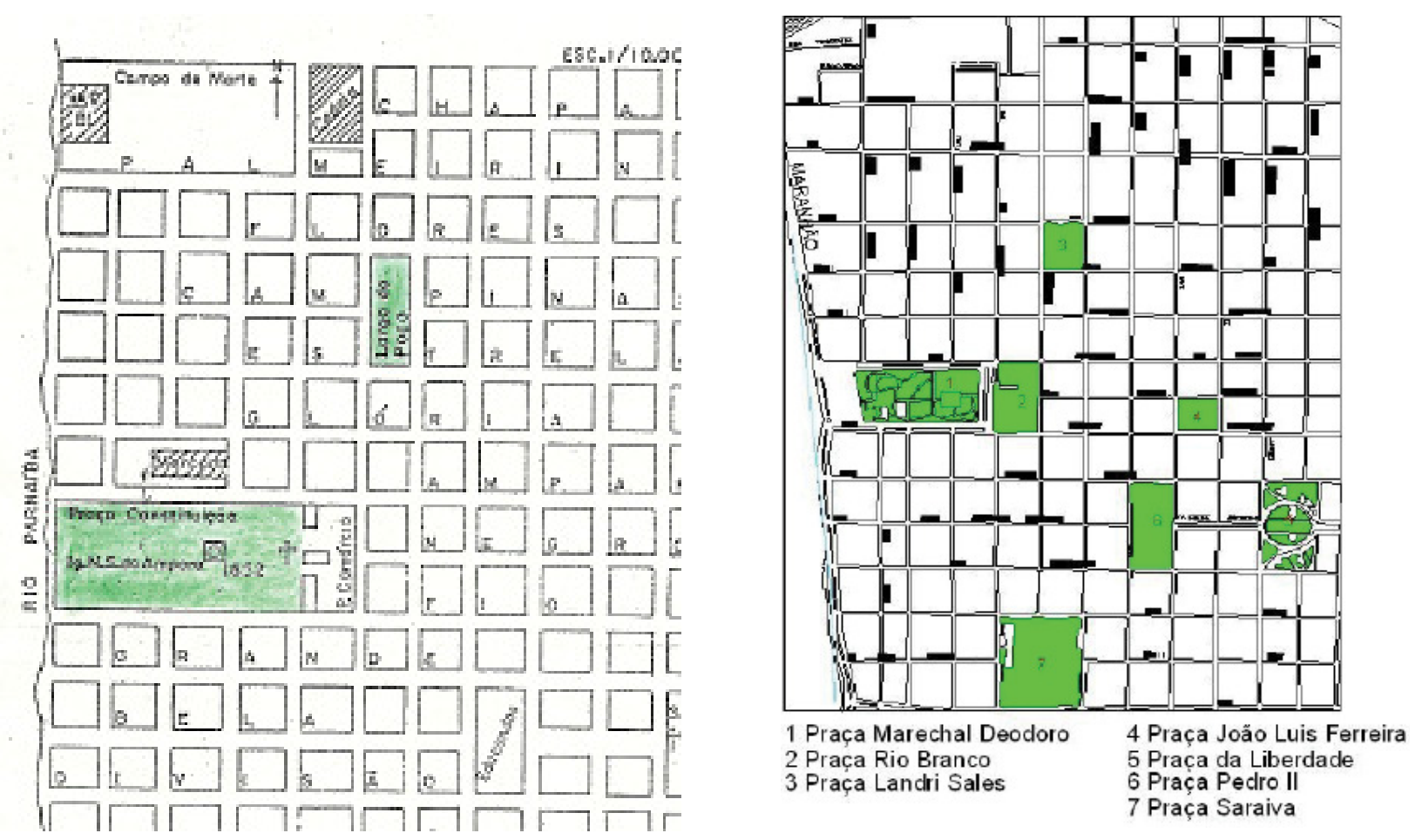

Figura 1 - Planta do projeto inicial da cidade de Teresina em 1852. Fonte: GOMES, 1992, p. 10 (à esquerda). Figura 2 - Localização das praças existentes atualmente no Centro Histórico de Teresina. Fonte: SEMPLAN adaptado por José Hamilton Leal Jr (à direrita).

Para o presente estudo foram selecionadas a Praça João Luís Ferreira e a Praça Landri Sales que, mesmo localizadas no centro da cidade e próximas entre si, apresentam características diversas, sendo este aspecto determinante no processo de seleção das áreas estudadas.

A Praça João Luís Ferreira, situada entre as ruas Elizeu Martins, Sete de Setembro, Coelho Rodrigues e David Caldas, está inserida num entorno caracterizado pela concentração de atividades de comércio e de serviços, apresentando intenso fluxo de transportes coletivos, de carros e de motos. Caracteriza-se por ser um espaço bastante arborizado, local de passagem de transeuntes e por apresentar forte presença de atividades comerciais informais, as quais são realizadas nos passeios e 
nos canteiros, com a colocação de bancas para a venda de mercadorias, como eletrônicos, comidas, roupas, artesanato, entre outros produtos.

Em 2000, a praça passou por uma reforma com o objetivo de resgatar alguns elementos arquitetônicos, como postes e bancos, que marcaram a identidade da praça. Com a reforma, foram inseridos dois pontos de ônibus, que atraíram o comércio informal, devido à concentração de pessoas. Os bancos estão distribuídos em todo espaço sombreado da praça, sendo um atrativo a mais, devido a sua grande massa arbórea que produz um microclima agradável e convidativo.

A Praça Landri Sales, também conhecida como Praça do Liceu, está localizada entre as ruas Benjamim Constant, Barroso, Desembargador Freitas e Simplício Mendes e possui menor índice de arborização. Embora também apresente em seu entorno a predominância de atividades de comércio e de serviços, ainda são encontradas edificações residenciais nas proximidades e o Colégio Estadual Zacarias de Góis, conhecido como Liceu Piauiense, tendo fluxo moderado de carros, motos e bicicletas.

\section{PROCEDIMENTOS METODOLÓGICOS}

Para a coleta das variáveis climáticas, em cada praça, foram selecionados dois pontos internos, um que estivesse sob o efeito de sombreamento, com vegetação (CV) e outro, submetido aos efeitos da insolação direta, sem vegetação (SV). Na Praça João Luís Ferreira, que é bastante arborizada, o Ponto $1(\mathrm{CV})$, referente ao local com vegetação está situado em um dos passeios principais, em que é grande o fluxo de pessoas e do comércio informal (Figura 3). O Ponto 2 (SV), sujeito à incidência direta do sol, está localizado quase na parte central da praça, revestida com piso de pedra portuguesa e sem a presença de árvores (Figura 4).

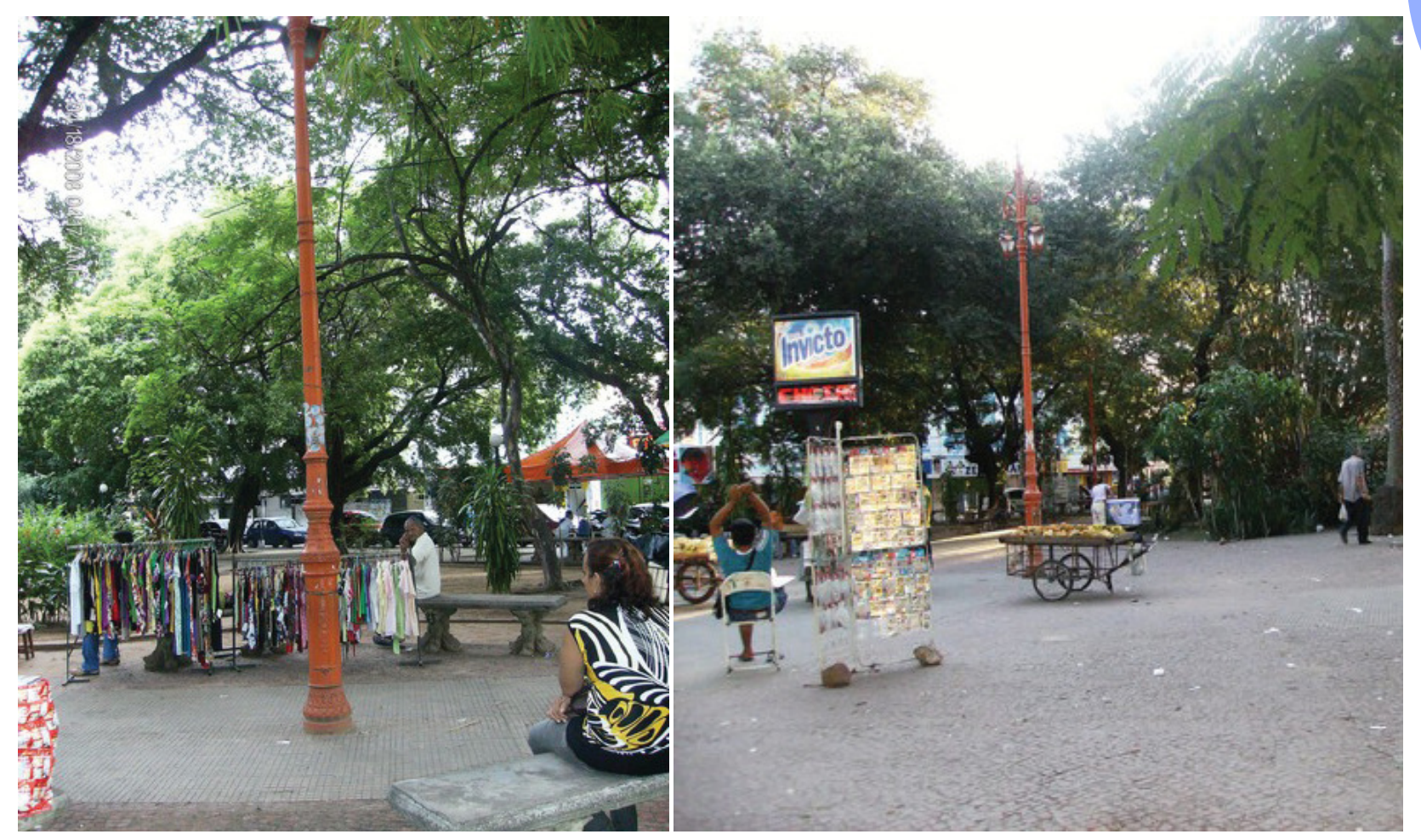

Figura 3 - P1 com vegetação (CV) na Praça João Luís Ferreira (à esquerda). Fonte: Foto Guilhermina Castro (2008).

Figura 4 - P2 sem vegetação (SV) na Praça João Luís Ferreira (à direita). Fonte: Foto Guilhermina Castro (2008).

Na Praça Landri Sales o Ponto 1 (Figura 5), relacionado ao local mais sombreado (CV), está situada em um canteiro, com pouca presença de grama batatais (Paspalum notatum). O Ponto 2 
(Figura 6), sujeito à incidência direta do sol (SV), está localizado nas proximidades da escadaria, apresentando piso de concreto e de pedra portuguesa, em que os raios solares incidem durante o dia.

Foram efetuadas medições de temperatura e de umidade relativa do ar, durante sete dias consecutivos, alternando entre a segunda e a terceira semana de cada mês, no período de agosto a novembro de 2008, nos horários de $9 \mathrm{~h} 00 \mathrm{~min}, 15 \mathrm{~h} 00 \mathrm{~min}$ e $21 \mathrm{~h} 00 \mathrm{~min}$, segundo os padrões internacionais da Organização Meteorológica Mundial (World Meteorological Organization - WMO). Foi utilizado o Termo-higrômetro digital, modelo HT-157 Instrutherm, a uma altura de 1,10 m do solo.

Os dados coletados em campo foram correlacionados com os dados climáticos da estação meteorológica do Instituto Nacional de Meteorologia (INMET), localizada na Estação experimental da Empresa Brasileira de Pesquisa Agropecuária - Embrapa Meio Norte, correspondentes ao mesmo período e horário das medições móveis. Este comparativo auxiliou na compreensão das possíveis flutuações ocorridas nos período de desenvolvimento do trabalho.

A arborização existente, em cada praça, foi registrada e quantificada, a partir de observação direta, com a identificação do nome científico, nome popular, família e percentual de cada espécie no local, visando identificar sua atuação na melhoria do conforto ambiental destes espaços.

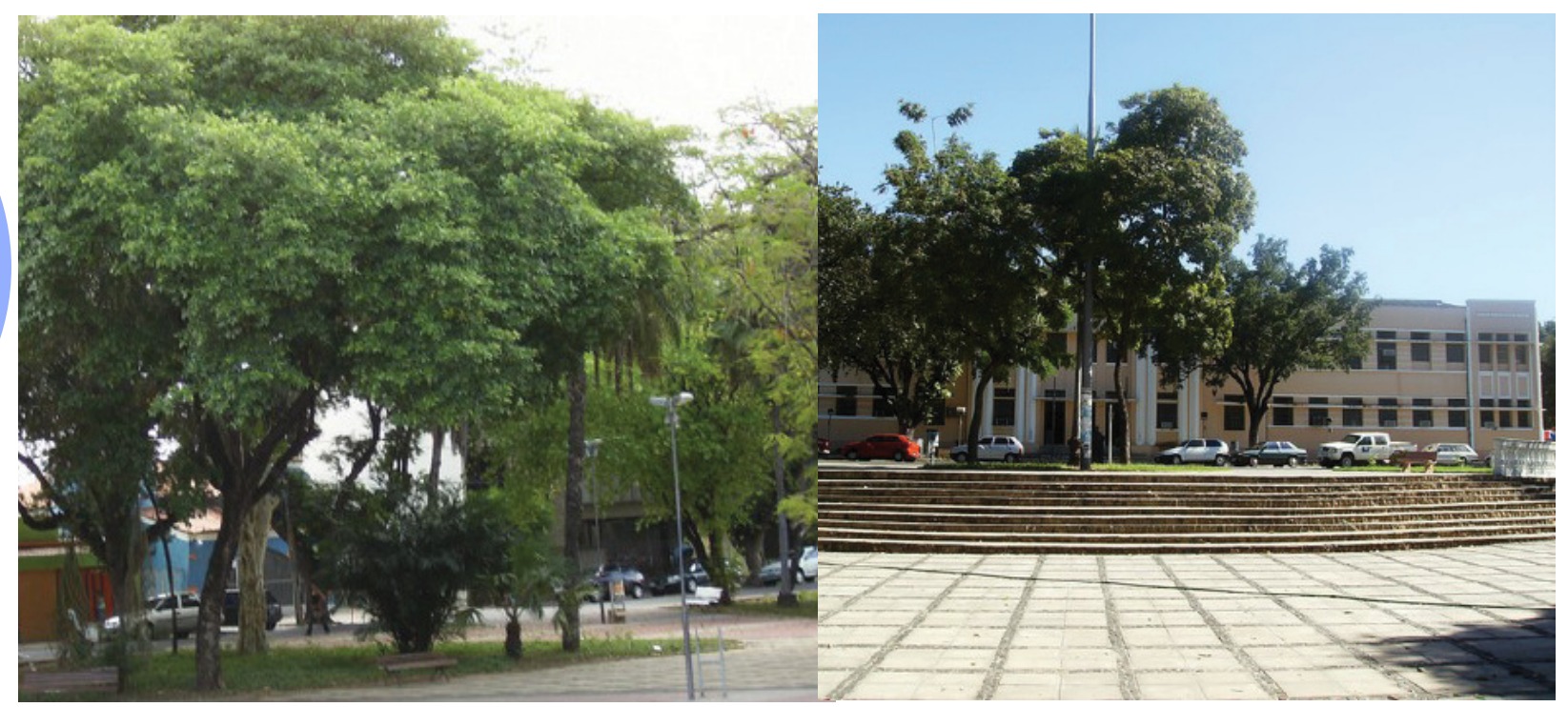

Figura 5 - P1 com vegetação (CV) na Praça Landri Sales. Fonte: Foto Guilhermina Castro (2008) (à esquerda). Figura 6 - P2 sem vegetação (SV) na Praça Landri Sales. Fonte: Foto Guilhermina Castro (2008) (à direita).

Foram aplicados 40 questionários em cada praça, com o objetivo de identificar a percepção ambiental dos usuários em relação aos espaços estudados, em especial em relação à arborização urbana existente no local. O questionário foi baseado em Oliveira (2005) e De Angelis et al. (2004), enfocando questões relacionadas ao perfil do entrevistado (sexo, idade, escolaridade, renda, ocupação), aos tipos de atividades realizadas e frequência de uso do local, a importância das praças para a cidade e a influência da arborização na melhoria de temperatura, entre outras.

\section{RESULTADOS}

\section{As praças e as árvores}

A Praça João Luís Ferreira possui uma área total de 5.030,07 m2, com 51\% da área apresentando cobertura vegetal, o que corresponde a 2.569,42 $\mathrm{m}^{2}$. Há predominância de árvores de grande porte como oiti (Licania tomentosa), figueira (Ficus microcarpa) e canafístula (Cassia grandis L.F.), formando grande área sombreada, o que favorece a permanência dos usuários neste espaço. Essas 
árvores circundam a praça formando um cinturão verde (Figura 7) em contraste com as construções existentes em seu entorno.

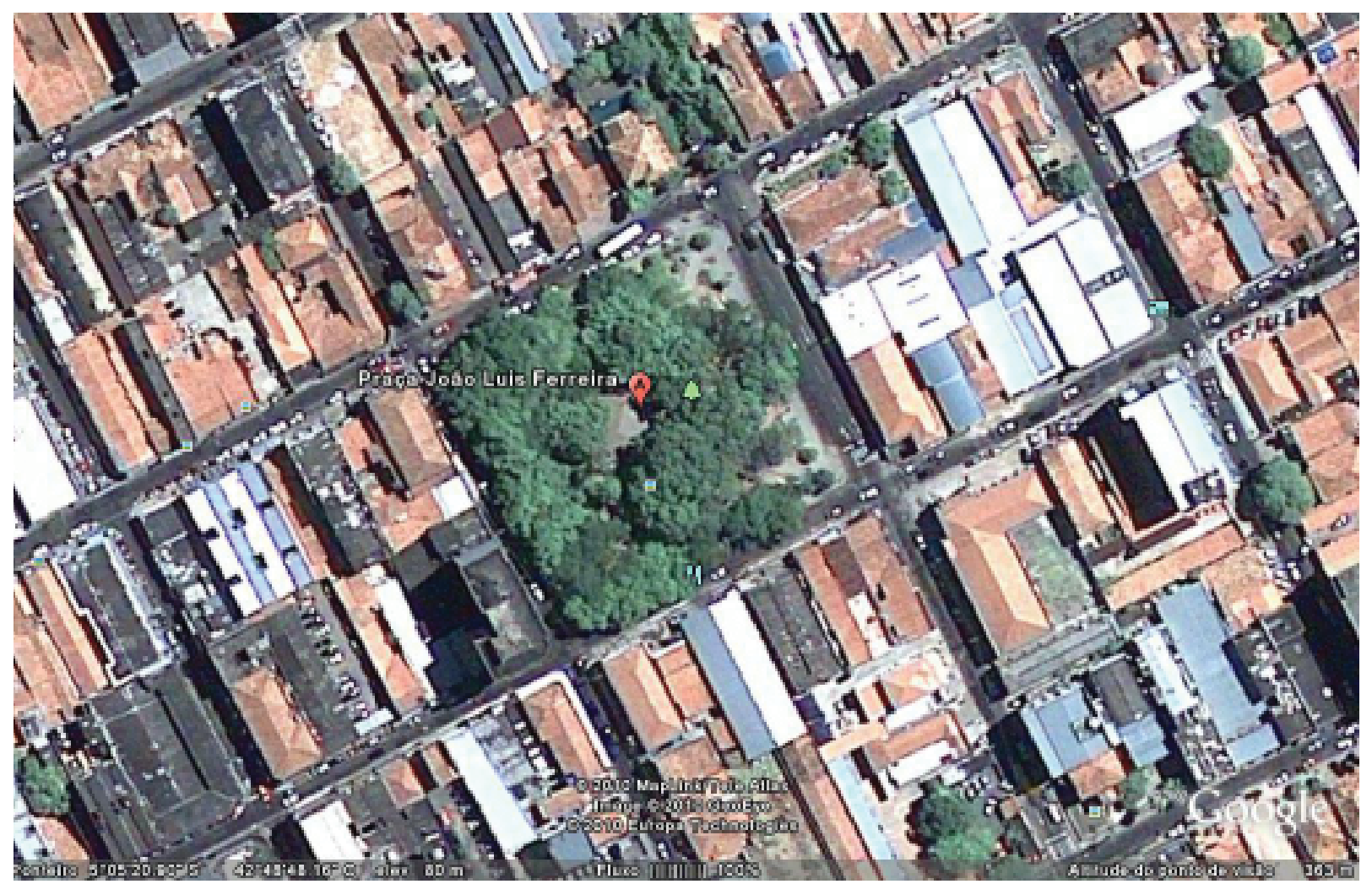

Figura 7: Vista aérea da Praça João Luis Ferreira. Fonte: Google Earth (2009)

$\mathrm{Na}$ Tabela 1, encontram-se os dados do levantamento arbóreo das espécies existente na Praça João Luis Ferreira.

Tabela 1 - Espécies arbóreas existentes na Praça João Luis Ferreira

\begin{tabular}{c|c|c|c|c}
\hline Nome científico & Nome popular & Família & Quant. & $\begin{array}{c}\text { Percentual } \\
\text { (\%) }\end{array}$ \\
\hline Licania tomentosa (Benth.) Fritsch & Oiti & Chrysobalanaceae & 23 & 37,7 \\
\hline Cassia grandis L.F. & Canafístula & $\begin{array}{c}\text { Leguminosae- } \\
\text { Caesalpinoideae }\end{array}$ & 14 & 23,0 \\
\hline Ficus microcarpa & Figueira & Moraceae & 13 & 21,3 \\
\hline Copernicia prunifera (Miller) H. E. Moore & Carnaúba & Palmae (Arecaceae) & 03 & 5,0 \\
\hline Bambusa vulgaris & Bambu & Poaceae & 02 & 3,3 \\
\hline Delonix regia (Bojer ex Hook.) Raf. & Flamboyant & Fabaceae & 02 & 3,3 \\
\hline Orbignya speciosa (Mart.) Barb. Rodr & Babaçu & Palmae (Arecaceae) & 01 & 1,6 \\
\hline Acacia podalyriifolia & Acácia mimosa & Mimosaceae & 01 & 1,6 \\
\hline Caesalpina férrea Mart. ex Tul. var. férrea & Pau ferro/ jucá & Caesalpinoideae & 01 & 1,6 \\
\hline Adenanthera pavonina L. & Tento Carolina & Leguminosae (Fabaceae) & 01 & 1,6 \\
\hline
\end{tabular}

Neste espaço, foi constatada a presença de sete famílias e dez espécies, sendo que o oiti (Licania tomentosa Benth. Fritsch) tem presença marcante na praça e na cidade. Trata-se de espécie bastante utilizada, tanto em praças como em ruas e avenidas, como é o caso da Avenida Centenário e da Avenida Frei Serafim, importantes e conhecidas vias de circulação da cidade de Teresina. Segundo Lorenzi (2002, p. 101), esta árvore fornece excelente sombra, tornando-se "preferida para plantio em praças, jardins, ruas e avenidas". 
A canafístula (Cassia grandis L. F.), segunda planta mais abundante na Praça João Luis Ferreira, atinge a altura de até $20 \mathrm{~m}$, sendo uma planta extremamente ornamental, devido à sua beleza, no período da floração, podendo, assim, ser usada em projetos paisagísticos. É muito empregada na arborização de avenidas, praças e parques. Sua copa, além de larga, é frondosa, chegando apresentar $8 \mathrm{~m}$ de diâmetro. Possui folhas pequenas e caducas, que se perdem entre outono e inverno (LORENZI, 2002; PIVETA; SILVA FILHO, 2002).

Foi observado que, as árvores, sendo a maioria de grande porte, estão bem conservadas. No entanto, há pouca presença de arbustos e de forração, devido principalmente, às atividades de comércio informal, que se utilizam dos canteiros para expor as mercadorias, embora, existam alguns desses canteiros que apresentem áreas revestidas de grama, em locais onde é menor a presença dos comerciantes.

Na Praça Landri Sales a arborização é diversificada e está distribuída em todo o seu espaço (Figura 8).

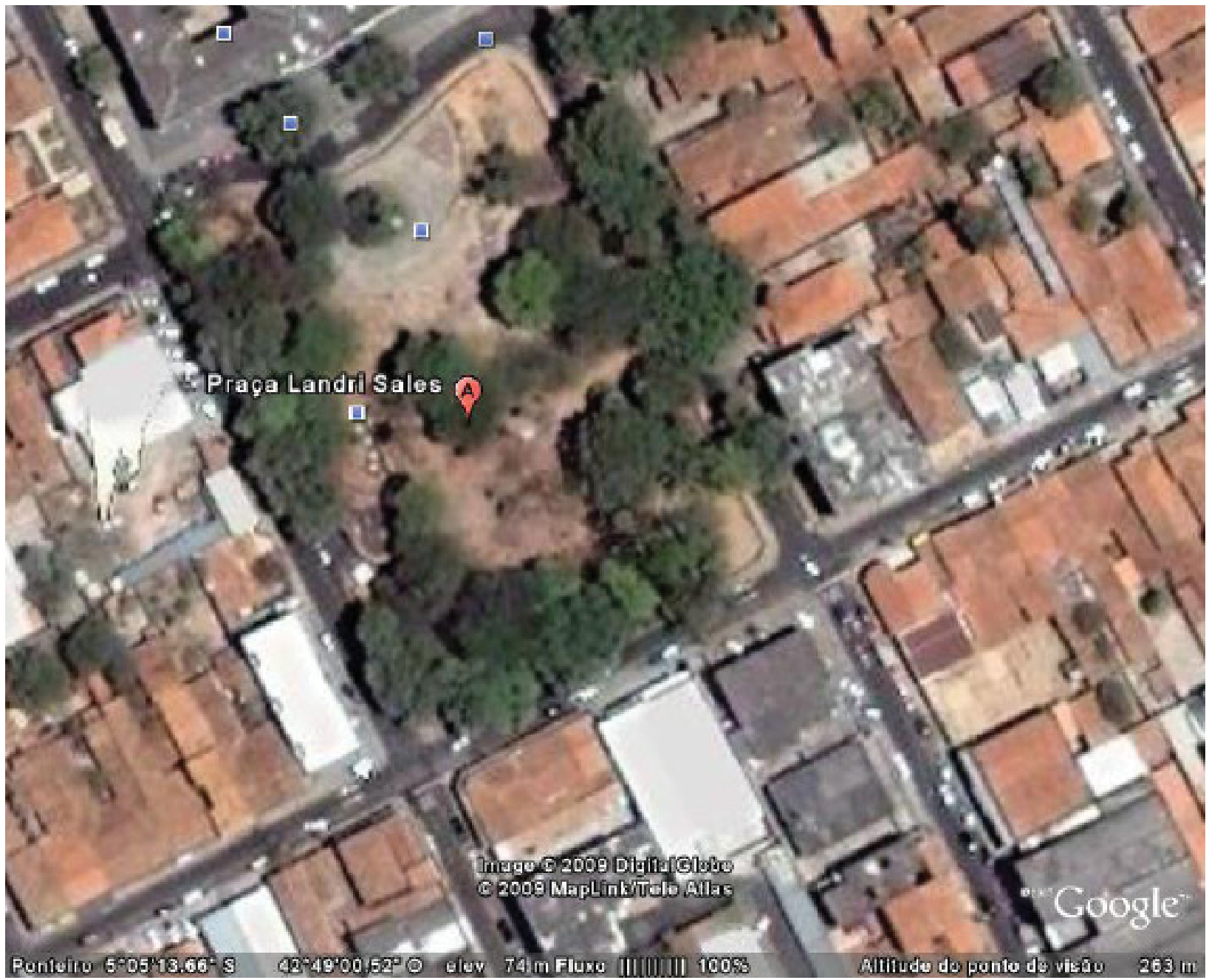

Figura 8: Vista aérea da Praça Landri Sales

Fonte: Google Earth (2009)

Alguns canteiros não comportavam as raízes de certas plantas, danificando o piso, o que foi modificado com a reforma, realizada em 2006, quando foram ampliados, de acordo com o porte das árvores, proporcionando o espaço necessário para o seu desenvolvimento, favorecendo a harmonização entre a área de passeio e a de cobertura vegetal.

A vegetação de porte arbóreo é bastante significativa, contribuindo para o uso do espaço e para a sensação de conforto e bem estar aos usuários. As árvores estão dispostas por toda a área da praça proporcionando uma área sombreada. 
$\mathrm{Na}$ Praça Landri Sales foram encontradas 13 famílias e 21 espécies, listadas na Tabela 2, constando o nome científico, nome popular, quantidade e percentual das espécies existentes, porém, uma espécie não foi identificada.

Tabela 2 - Espécies arbóreas existentes na Praça Landri Sales

\begin{tabular}{|c|c|c|c|c|}
\hline Nome científico & Nome popular & Família & Quant. & Percentual (\%) \\
\hline $\begin{array}{l}\text { Caesalpina férrea Mart. ex Tul. var. } \\
\text { férrea }\end{array}$ & Pau ferro/ jucá & Caesalpinoideae & 10 & 13,3 \\
\hline Licania tomentosa (Benth.) Fritsch & Oiti & Chrysobalanaceae & 09 & 12,0 \\
\hline Syagrus oleracea & Paty & Palmae (Arecaceae) & 07 & 9,4 \\
\hline Delonix regia (Bojer ex Hook.) Raf. & Flamboyant & Fabaceae & 07 & 9,4 \\
\hline $\begin{array}{l}\text { Copernicia prunifera (Miller) H. E. } \\
\text { Moore }\end{array}$ & Carnaúba & Palmae (Arecaceae) & 07 & 9,4 \\
\hline Orbignya speciosa (Mart.) Barb. Rodr & Babaçu & Palmae (Arecaceae) & 06 & 8,0 \\
\hline Zizyphus joazeiro Mart. & Juazeiro & Ramnaceae & 05 & 6,7 \\
\hline $\begin{array}{c}\text { Tabebuia serratifolia (Vahl.) G. } \\
\text { Nicholson }\end{array}$ & Ipê amarelo & Ramnaceae & 03 & 4,0 \\
\hline $\begin{array}{c}\text { Acrocomia aculeata (Jacq.) Lodd. Ex } \\
\text { Mart. }\end{array}$ & Macaúba & Palmae (Arecaceae) & 03 & 4,0 \\
\hline Vitex flavens & Mama cachorra & Verbenaceae & 03 & 4,0 \\
\hline $\begin{array}{c}\text { Couepia grandiflora (Mart. \& Zucc.) } \\
\text { Benth. ex Hookf. }\end{array}$ & Oiticica & Chrysobalanaceae & 03 & 4,0 \\
\hline Caesalpina echinata Lam. & Pau Brasil & Leguminosae-Caesalpinoideae & 02 & 2,7 \\
\hline Terminalia SP & Pau d'água & Combretaceae & 02 & 2,7 \\
\hline Clitoria fairchildiana R. A. Howard & Acácia azul & Leguminosae-Papilioideae & 01 & 1,3 \\
\hline Anadenanthera colubrina & Angico branco & Fabaceae & 01 & 1,3 \\
\hline Espécie não identificada & Figueira & $\underline{-}$ & 01 & 1,3 \\
\hline Plumeria rubra L. & Jasmim manga & Plumeria rubra L. & 01 & 1,3 \\
\hline Mangifera indica & Mangueira & Anacardiaceae & 01 & 1,3 \\
\hline Talisia esculenta (A. St.-Hil.) Radlk. & Pitombeira & Sapindaceae & 01 & 1,3 \\
\hline Astrocaryum vulgare Mart. & Tucum & Arecaceae & 01 & 1,3 \\
\hline Adenanthera pavonina (L.) & Tento Carolina & Leguminosae (Fabaceae) & 01 & 1,3 \\
\hline
\end{tabular}

Entre as espécies mais encontradas na Praça Landri Sales, o Pau ferro (Caesalpina férrea) se destaca com 13,3\% e o Oiti (Licania tomentosa) com 12\%. O flamboyant (Delonix regia), embora não produza sombra densa, apresenta floração expressiva, simbolizando uma espécie de grande beleza, tendo no contexto dessa praça uma contribuição de 9,4\%, entre as espécies existentes no local.

O mesmo ocorre em relação ao babaçu (Orbignya speciasa) e a carnaúba (Copernicia prunifera), que embora não possibilitem espaços sombreados, são palmeiras que embelezam e proporcionam um aspecto peculiar ao local. Inclusive, quando a praça foi criada, Cavalcanti $(1958$, p. 7$)$ descreveu sua arborização como "[...] genuinamente piauiense notando-se o cabeça-de-frade, o pati, o lírio, o capim rasteiro, algumas rosáceas, pés de páu-d'arco e algumas palmeiras altas".

O Pau ferro (Caesalpina férrea Mart. ex Tul. var. férrea) é uma árvore que pode chegar a 15 $\mathrm{m}$, tendo tronco curto de 40-60 cm de diâmetro e com bifurcações quando isolada. É uma espécie ornamental com copa arredondada, baixa e rala, recomendada para arborização de praças, parques, ruas, avenidas e estacionamentos (LORENZI, 2002).

De acordo com Gartland (2010), a vegetação tem um papel importante na minimização da temperatura nas áreas pavimentadas, como os centros urbanos. Isso se dá pelo sombreamento proporcionado pelas copas das árvores, que diminui a temperatura das superfícies e pelo processo de fotossíntese através da evapotranspiração que refresca o ar, aumentando sua umidade relativa. Ainda segundo a citada autora, em locais com clima seco e desértico o aumento da umidade através 
da vegetação traz benefícios em relação à ilha de calor gerada, entre outros fatores, pela impermeabilização do solo em áreas centrais urbanas.

\section{Aspectos climáticos das praças}

Os valores médios de temperatura, obtidos nas praças João Luís Ferreira e Landri Sales associados ao tipo de ambiente (com vegetação - CV e sem vegetação - SV) em função dos horários de coleta de dados, encontram-se apresentados na Tabela 3 e Figura 9.

Tabela 3 - Valores médios de temperatura $\left({ }^{\circ} \mathrm{C}\right)$ das praças João Luís Ferreira e da Praça Landri Sales referente ao tipo de ambiente em função do horário de coleta

\begin{tabular}{|c|c|c|c|c|c|}
\hline \multirow[b]{2}{*}{ Horário } & \multirow[b]{2}{*}{ Praça } & \multicolumn{3}{|c|}{ Tipo Ambiente $\left({ }^{\circ} \mathrm{C}\right)$} & \multirow[b]{2}{*}{${\text { Estaçã } 0^{1}}^{1}$} \\
\hline & & $\mathrm{CV}$ & SV & Média & \\
\hline \multirow{2}{*}{9} & João Luís & $32,58^{\mathrm{aB}^{*}}$ & $32,97^{\mathrm{aA}^{*}}$ & 32,78 & \multirow{2}{*}{$29,95^{*}$} \\
\hline & Landri Sales & $32,47^{\mathrm{aB}^{*}}$ & $34,39^{\mathrm{aA}^{*}}$ & 33,43 & \\
\hline \multicolumn{2}{|c|}{ Média } & 32,52 & 33,68 & & \\
\hline \multirow{2}{*}{15} & João Luís & $36,88^{\mathrm{bB}}$ & $37,88^{\mathrm{aA}}$ & 37,38 & \multirow{2}{*}{$36,74^{*}$} \\
\hline & Landri Sales & $38,13^{\mathrm{aB}^{*}}$ & $39,39^{\mathrm{aA}^{*}}$ & 38,76 & \\
\hline \multicolumn{2}{|c|}{ Média } & 38,00 & 38,14 & & \\
\hline \multirow{2}{*}{21} & João Luís & $33,80^{\mathrm{aA}^{*}}$ & $33,76^{\text {a }}$ & 33,78 & \multirow{2}{*}{$29,43^{*}$} \\
\hline & Landri Sales & $33,78^{\mathrm{aA}^{*}}$ & $33,94^{\mathrm{aA}^{*}}$ & 33,86 & \\
\hline \multicolumn{2}{|c|}{ Média } & 33,79 & 33,85 & & \\
\hline \multicolumn{2}{|c|}{ Coeficiente de variação (\%) } & \multicolumn{3}{|c|}{3,48} & \\
\hline
\end{tabular}

Médias na coluna, para o mesmo horário e mesmo tipo de ambiente, seguidas da mesma letra minúscula, não diferem entre si, pelo teste $t$ de Student $(\mathrm{P}>0,05)$; Médias na linha, para o mesmo horário e mesma praça, seguidas da mesma letra maiúscula, não diferem entre si, pelo teste t de Student ( $\mathrm{P}>0,05)$; Médias, seguidas de asterisco, para o mesmo horário, não diferem do tratamento controle, pelo teste de Dunnett $(\mathrm{P}>0,05)$.

(1) Estação Meteorológica da Embrapa Meio-Norte, localizada em Teresina, PI.

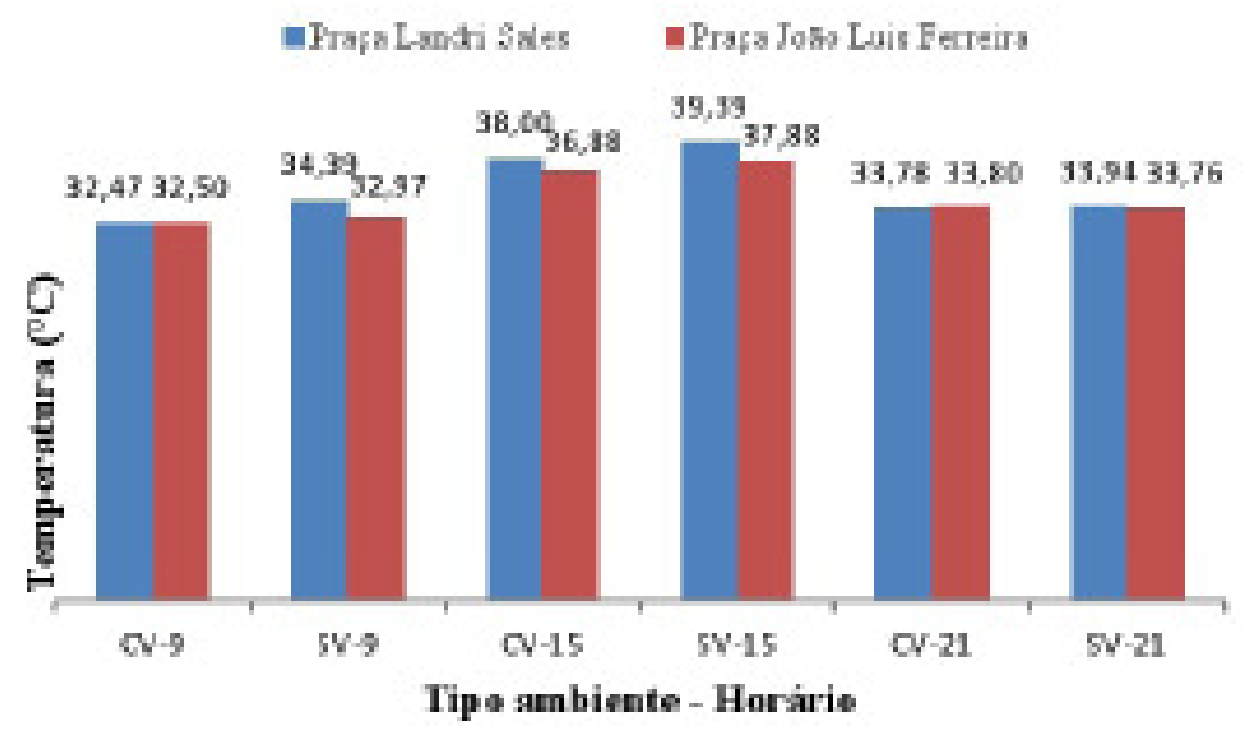

Figura 9 - Valores médios da Temperatura das Praças João Luís Ferreira e Landri Sales em função dos tipos de ambientes e horários de coleta

Constatou-se que houve interação $(\mathrm{P}<0,05)$ entre os fatores avaliados, praças (João Luís Ferreira e Landri Sales), tipo de ambiente (com vegetação - CV e sem vegetação - SV) e horários de coleta $(9 \mathrm{~h} 00,15 \mathrm{~h} 00$ e $21 \mathrm{~h} 00)$.

Observou-se nos horários de coleta de $9 \mathrm{~h} 00$ e 21 h00, que as médias de temperatura das praças 
João Luís Ferreira e da Praça Landri Sales, em ambiente com vegetação (CV) e sem vegetação $(\mathrm{SV})$, foram similares $(\mathrm{P}>0,05)$. No entanto, no horário das $15 \mathrm{~h} 00$, em que as temperaturas são mais elevadas, verificou-se que na Praça João Luís Ferreira, no ambiente com vegetação a temperatura foi menor $(\mathrm{P}<0,05)$, enquanto no ambiente sem vegetação, na Landri Sales, não houve diferença $(\mathrm{P}>0,05)$. Esta constatação reforça a importância da arborização na redução de temperatura nos períodos mais críticos, visto que a Praça João Luís Ferreira apresenta maior cobertura vegetal, amenizando os efeitos da insolação sobre as temperaturas.

Também, constatou-se que os valores médios da temperatura nas praças João Luís Ferreira e Landri Sales às $9 \mathrm{~h} 00$ e às $15 \mathrm{~h} 00$ foram mais elevados $(\mathrm{P}<0,05)$ nas áreas sem vegetação $(\mathrm{CV})$. No entanto, às $21 \mathrm{~h} 00$, os valores foram similares $(\mathrm{P}>0,05)$ para as duas praças estudadas $(\mathrm{P}>0,05)$. Estes resultados corroboram as afirmações de Castelo Branco (2003), ao afirmar que a arborização urbana, distribuída em ruas, avenidas e praças existentes na cidade, proporciona áreas sombreadas, ajudando a minimizar a temperatura nos meses mais quentes.

Faria e Mendes (2004, p. 13), ao compararem a temperatura do ar nas cidades de Bauru (Brasil) e Braga (Portugal), constataram que "as taxas relativas de aquecimento e de resfriamento do ar são menores quando a área apresenta cobertura vegetal significativa". Fontes et al (2005), em estudo envolvendo oito praças de Bauru (São Paulo), tiveram como resultado uma diferença de $3,1^{\circ} \mathrm{C}$ na área interna de uma das praças, o Bosque da Comunidade, que é caracterizada por um sombreamento denso.

Na comparação com os dados obtidos na Estação Meteorológica da Embrapa Meio-Norte, às $9 \mathrm{~h} 00$ e 21h00, com os demais resultados, provenientes da associação praças x tipo de ambiente, com exceção dos observados na Praça João Luís Ferreira sem vegetação (SV), os medidos na Estação Meteorológica foram inferiores aos demais $(\mathrm{P}<0,05)$. Convém destacar que a Estação da Embrapa fica em local afastado do centro da cidade e área bastante arborizada, o que pode contribuir para menores valores de temperatura do ar.

Os valores médios de umidade relativa do ar obtidos nas praças João Luís Ferreira e Praça Landri Sales associados ao tipo de ambiente em função dos horários de coleta de dados estão apresentados na Tabela 4 e na Figura 10.

Tabela 4 - Valores médios da umidade relativa do ar (\%) das praças João Luis Ferreira e Praça Landri Sales em função do tipo de ambiente e do horário de coleta

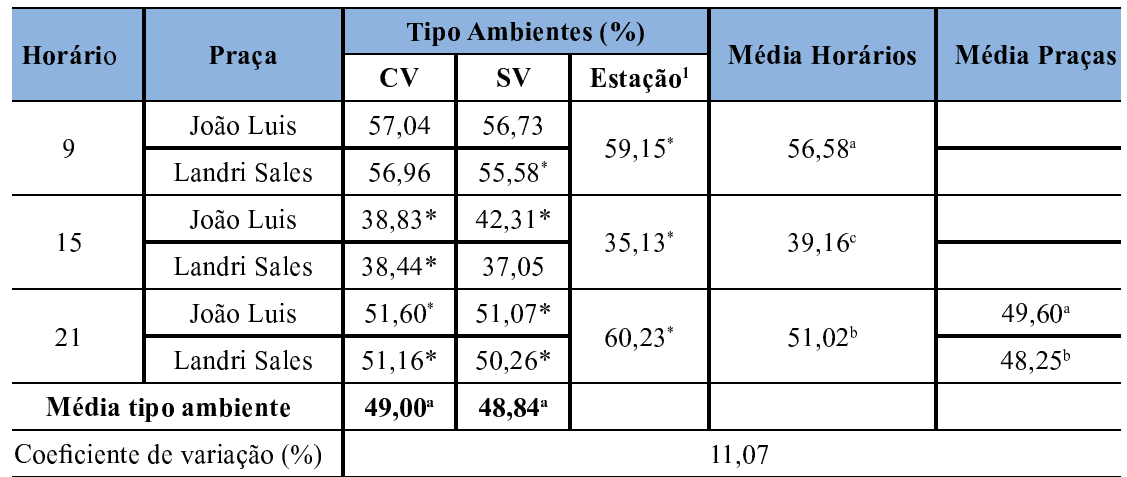

(1) Estação Meteorológica da Embrapa Meio-Norte, localizada em Teresina, PI.

Médias, na mesma linha ou na coluna, seguidas da mesma letra, não diferem entre si, pelo teste $\mathrm{SNK}(\mathrm{P}>0,05)$. Médias, seguidas de asterisco, para o mesmo horário, não diferem do tratamento controle, pelo teste de Dunnett $(\mathrm{P}>0,05)$. 


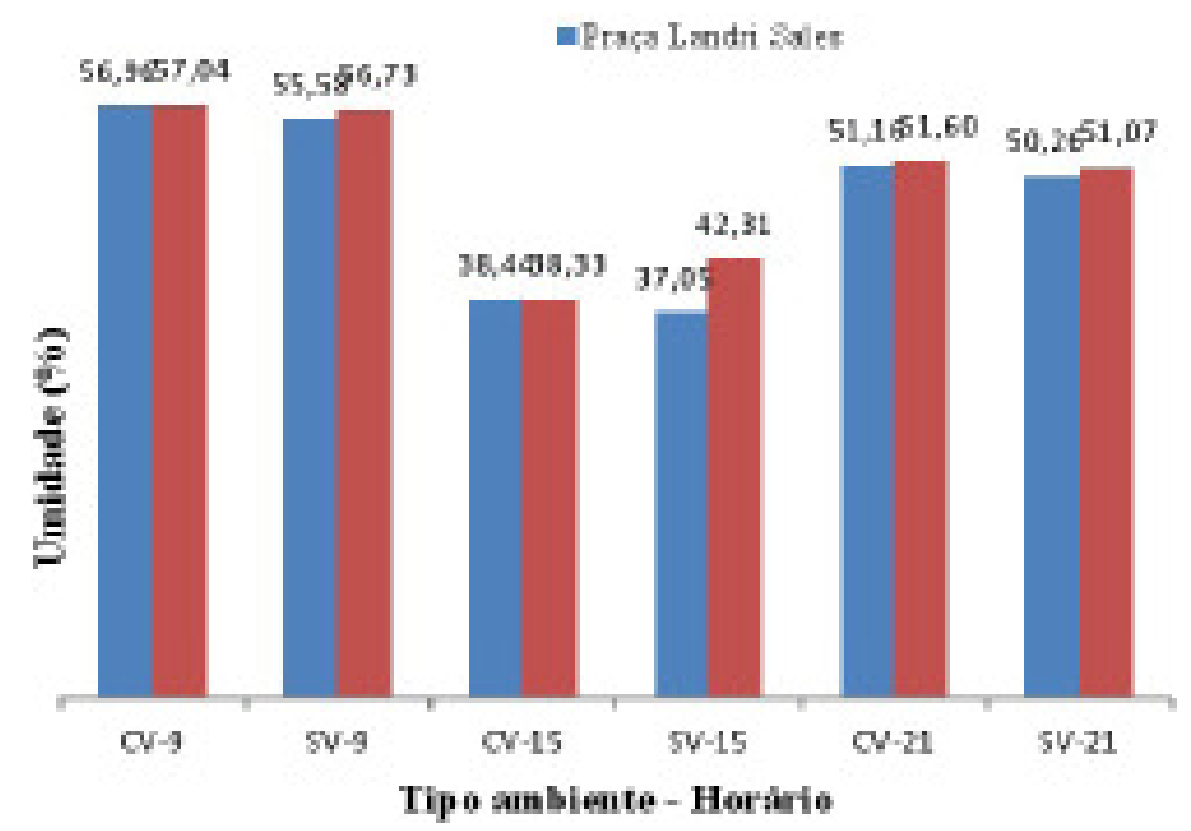

Figura 10 - Valores médios da umidade relativa do ar das Praças João Luís Ferreira e Landri Sales em função dos tipos de ambientes e horários de coleta

Constatou-se que não houve interação $(\mathrm{P}>0,05)$ entre os fatores avaliados, praças (João Luís Ferreira e Landri Sales), tipo de ambiente (com e sem vegetação) e horários de coleta (9h00, 15h00 e 21h00).

Os valores médios da umidade relativa do ar da Praça João Luís Ferreira foram superiores aos da Praça Landri Sales $(P<0,01)$, não havendo diferença entre os ambientes com e sem vegetação $(\mathrm{P}>0,05)$. Com relação aos horários de coleta, o maior valor de umidade foi obtido às $9 \mathrm{~h} 00$, sendo seguido das $21 \mathrm{~h} 00$ e $15 \mathrm{~h} 00(\mathrm{P}<0,01)$.

Na Praça João Luís Ferreira, às 9h00, com e sem vegetação e na Praça Landri Sales às 15 h00, sem vegetação, os valores da umidade relativa do ar foram similares aos obtidos na Estação Meteorológica da Embrapa $(\mathrm{P}>0,05)$. Entretanto, na Praça Landri Sales às $9 \mathrm{~h} 00$, sem vegetação e às $21 \mathrm{~h} 00$ para as duas praças, com e sem vegetação, os valores foram inferiores aos observados na Estação da Embrapa Meio-Norte $(\mathrm{P}<0,05)$. Às 15h00, para a Praça João Luís Ferreira, com e sem vegetação e para a Praça Landri Sales com vegetação, os valores encontrados foram superiores aos dados observados na Estação Meteorológica $(\mathrm{P}<0,05)$.

Algumas praças e avenidas do centro de Teresina costumavam ter fontes, representando um atrativo especial, além de que, a presença de água nestes locais contribuía para aumento da umidade, amenizando o desconforto térmico. Com o passar dos anos, grande parte das fontes destes espaços livres foram retiradas e aquelas ainda existentes, nas praças Da Costa e Silva, Marechal Deodoro da Fonseca e Rio Branco, estão desativadas. Para Frota e Schiffer (2003), espelhos de água e chafarizes devem estar presentes em espaços abertos em que o clima quente predomina, por ser um elemento de alteração de microclimas, que aumenta a umidade do ar ao evaporar, trazendo maior sensação de conforto às pessoas.

\section{Percepção dos usuários em relação à vegetação}

A pesquisa com os usuários tinha como objetivo identificar a percepção da população em relação aos benefícios proporcionados pela arborização, para a melhoria do conforto ambiental nas áreas urbanas. 
As praças exercem várias funções, que podem se modificar ao longo do tempo, acompanhando as transformações ocorridas na sociedade. Para Casé (2000, p. 61), as praças "têm de exercer a função lúdica, registrar a memória, promover atividades de lazer, incitar o intercâmbio cultural e o encontro espontâneo entre as pessoas".

Nos espaços estudados, o tópico referente sobre função mais marcante do local (Figura 11), revelou que a Praça João Luís Ferreira foi destacada como "ponto de referência", com 52,5\%, devido a sua localização central na área comercial da cidade. Enquanto que, a função mais marcante da Praça Landri Sales, foi a de "lugar de encontro", com 35\%.

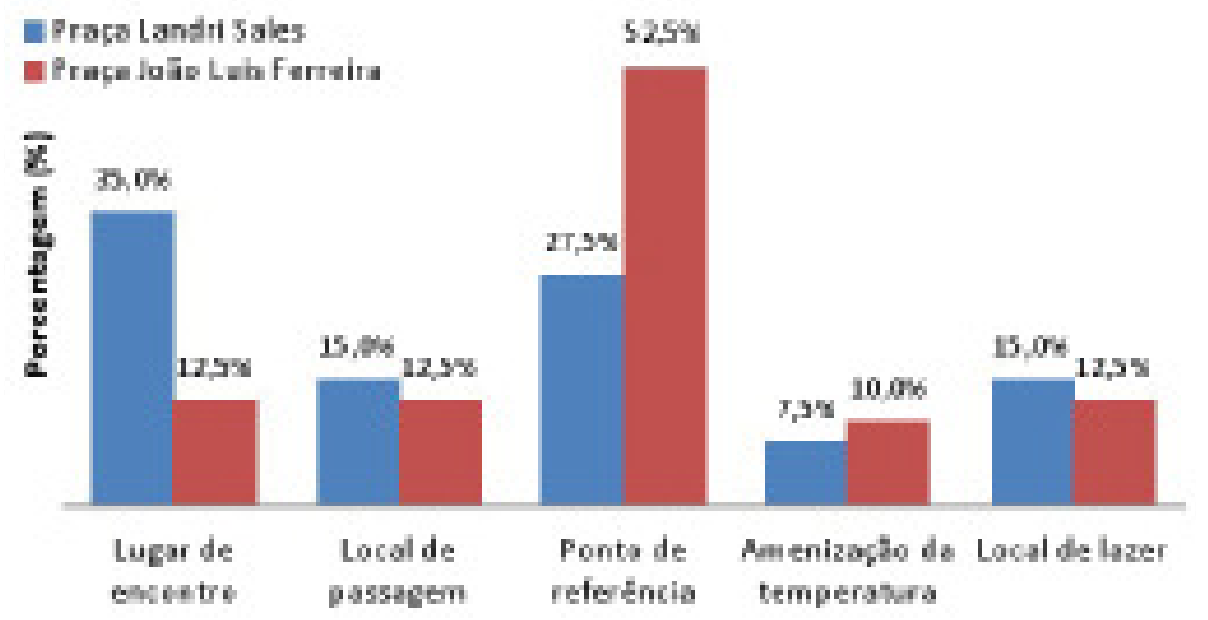

Figura 11 - Função mais marcante nas praças

Observou-se, ainda, que a função de "amenizar a temperatura" foi a que teve menor número de citações, nos dois espaços, mesmo pelos usuários da Praça João Luís Ferreira (10\%), local bastante arborizado. Mas, quando se questiona sobre o motivo que levou o usuário a escolher determinado local de permanência na praça, o mais citado foi a "sombra", com 42,5\%, nos dois espaços (Figura 12), comprovando a preferência pelos locais sombreados proporcionados pela vegetação, devido às altas temperaturas da cidade.

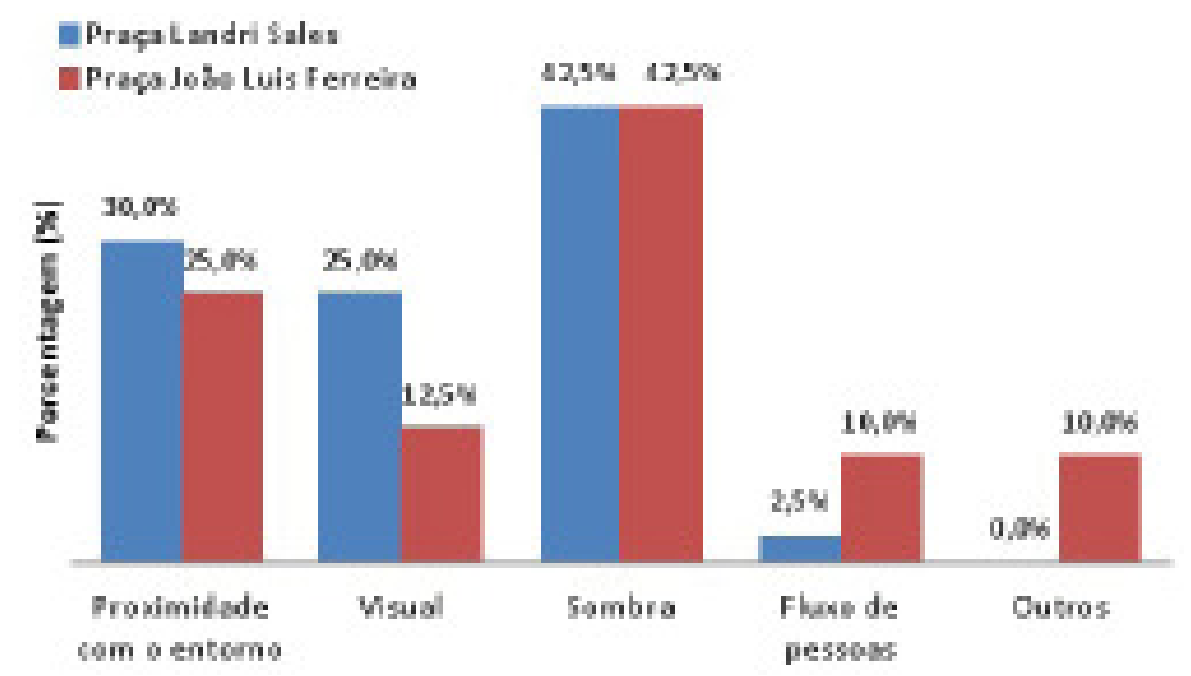

Figura 12 - Motivo da escolha do lugar nas praças 
A copa das árvores, que absorve parte dos raios solares, proporcionando áreas sombreadas, constitui em um dos benefícios da arborização, tendo um "papel importante na caracterização de microclimas urbanos, melhorando as condições ambientais adversas e o conforto humano" (MASCARÓ, 1996, p. 86). Para Fontes et al. (2005), a presença de espaços sombreados com bancos contribui para a permanência dos usuários nas praças, evidenciando uma forte relação entre uso e microclima.

No questionamento sobre o que mais chama a atenção dos usuários no espaço pesquisado (Figura 13), a maioria dos entrevistados apontou a vegetação, sendo 63\% dos usuários da Praça João Luís Ferreira e 47,5\% da Praça Landri Sales.

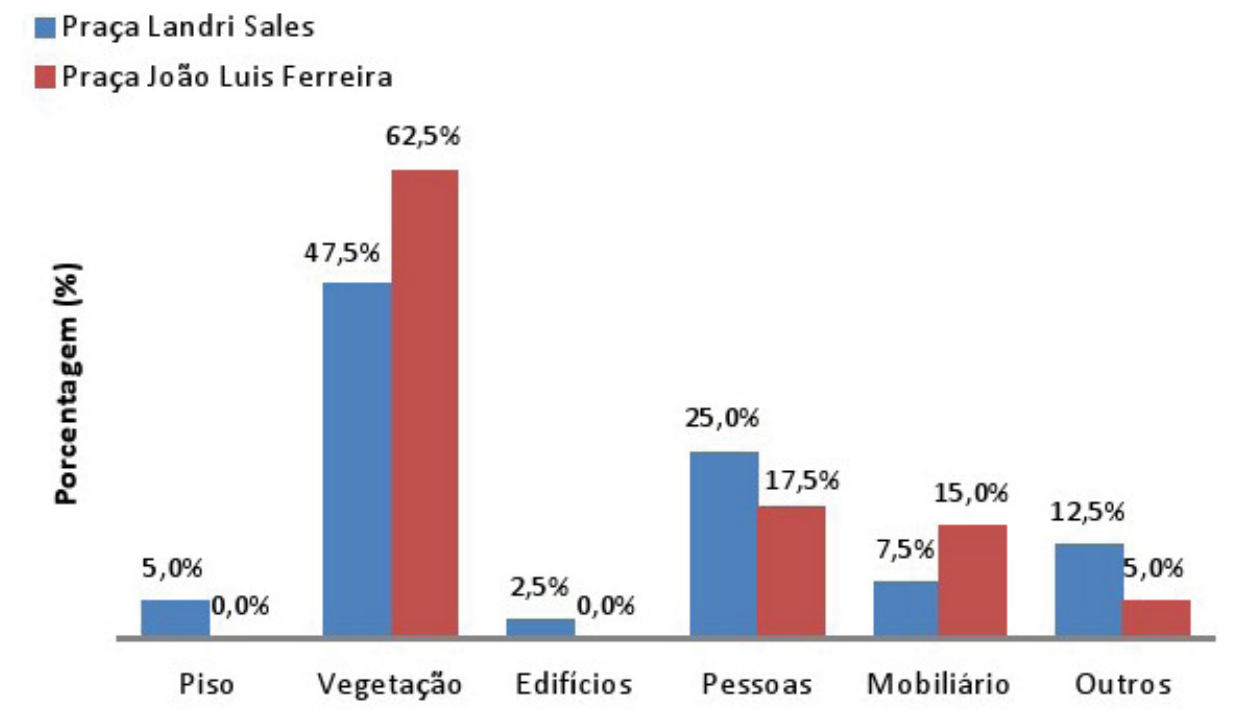

Figura 13 - O que chama a atenção do entrevistado no espaço e no entorno

Um dos benefícios da vegetação é a sombra que ela proporciona e a consequente redução de temperatura. Na Praça João Luís Ferreira, metade dos usuários entrevistados considerou que o espaço tem muita área sombreada e 32,5\% que há sombra suficiente, enquanto que, na Praça Landri Sales, $37,5 \%$ indicaram a presença de muita sombra e $25 \%$ consideram que há sombra suficiente, e ainda, $7,5 \%$ acham pequena a quantidade de sombra (Figura 14).

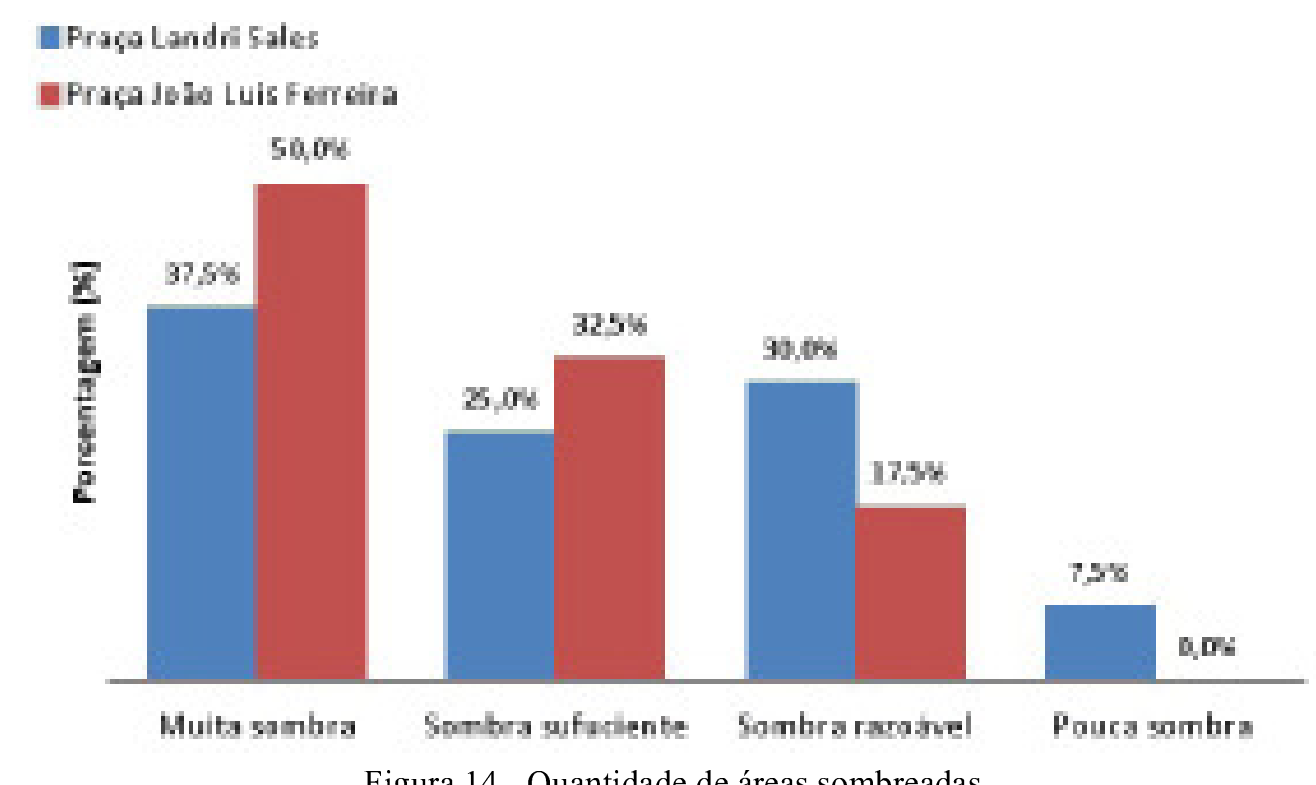

Figura 14 - Quantidade de áreas sombreadas 
Para Mascaró e Mascaró (2002), o sombreamento é uma das funções mais importantes da arborização urbana, sendo que a principal finalidade é amenizar o rigor térmico da estação quente, diminuir as temperaturas superficiais dos pavimentos e fachadas da edificação, como, também, diminuir a sensação de calor dos usuários (pedestres ou motorizados). Este aspecto foi percebido por $95 \%$ dos entrevistados, em ambas as praças, ao afirmarem que têm a sensação de menor temperatura na praça do que na rua. Esta sensação é percebida porque a temperatura do ar é amenizada pela vegetação através do controle da radiação e pela umidade que é liberada pelo vegetal através de suas folhas.

A presença da arborização nas praças, além de promoverem sombra, tem a função de ornamentação. Os projetos de reforma implantados nestes espaços estudados tinham o objetivo de colocar plantas ornamentais junto às árvores, uma forma de valorizar e embelezar o espaço com plantas e flores, dando um colorido nos canteiros.

O projeto paisagístico não foi devidamente implantado e, atualmente, grande parte dos canteiros não possui grama, apresentando pequena quantidade de plantas ornamentais, sendo que as árvores de grande e médio porte são as que permanecem até hoje. Os entrevistados acham que os canteiros e a vegetação das praças embelezam o local e melhoram o clima. Entretanto, alguns entrevistados acharam que estes elementos impedem a visão do entorno (Figura 15).

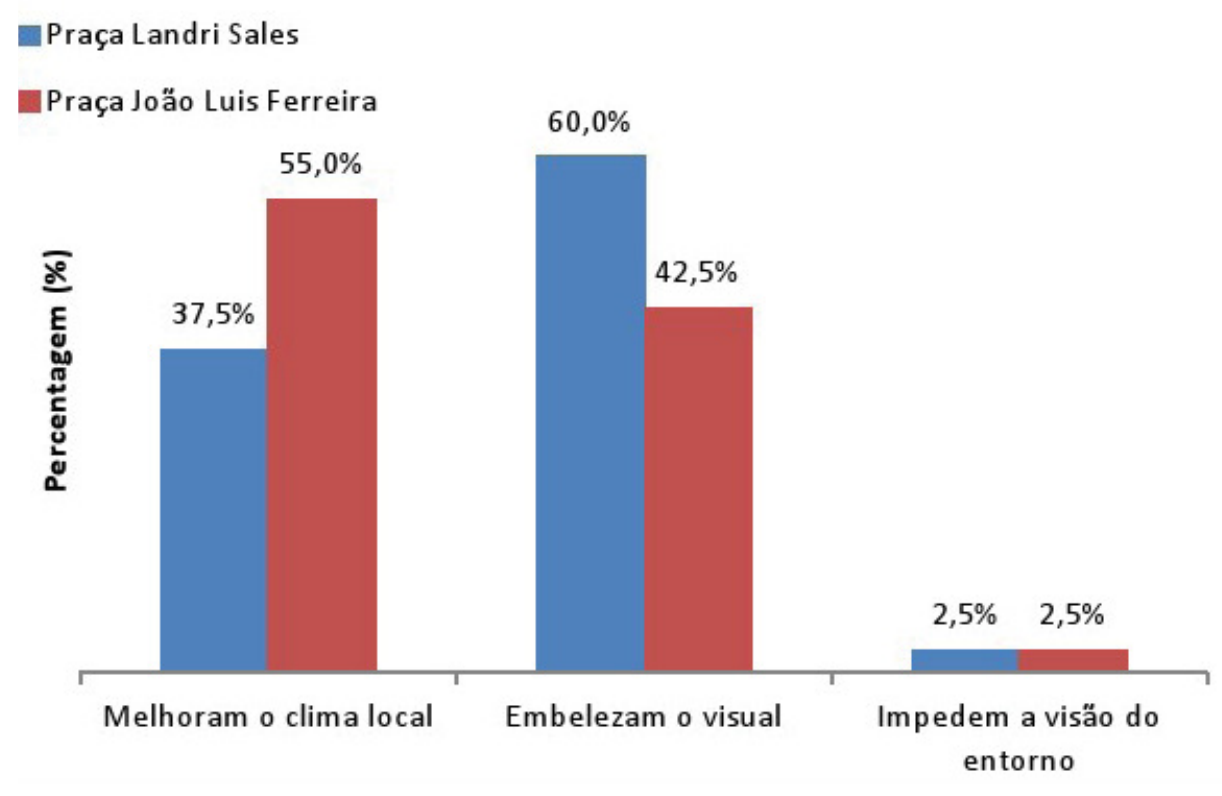

Figura 15 - Opinião sobre os canteiros e as árvores nas praças

Por meio de perguntas abertas feitas aos usuários dos espaços estudados, procurou-se identificar os aspectos que mais agradam e aqueles que mais desagradam e, ainda, sugestões para melhoria dos locais estudados.

Nem todos entrevistados responderam essas questões, mas as respostas foram similares para as duas praças. Os aspectos relacionados ao conforto térmico, como a arborização, a sombra e o clima, foram os mais citados positivamente (46 pessoas), mostrando que a presença significativa de árvores nestas praças favorece a sensação de menor temperatura, principalmente, na Praça João Luís Ferreira, devido à sua área sombreada. Esta sensação do conforto térmico nas praças ser maior que o do seu entorno se deve a alguns fatores antrópicos, como a impermeabilização do solo, aumento de superfícies refletoras e do tráfego de veículos que aumentam a temperatura.

Outros pontos positivos citados dos espaços estudados foram: o fluxo de pessoas (10 pessoas), tranquilidade (5 pessoas), sendo que na Praça João Luís Ferreira foi destacado o ponto de ônibus e na Praça Landri Sales, a praça de alimentação, que são elementos característicos de cada espaço. 
Os pontos negativos foram: a sujeira (11 pessoas), os bancos ( 9 pessoas), o barulho (4 pessoas) e o comércio informal. Estes pontos negativos, na sua maioria, devem-se ao grande fluxo de pessoas que são atraídas para os espaços, principalmente, pelo ponto de ônibus e pela presença do comércio informal, na Praça João Luís Ferreira, enquanto que na Praça Landri Sales pela presença de colégios nas proximidades. Também foi apontada a presença de mosquitos na Praça João Luís Ferreira e de formigueiros nos canteiros da Praça Landri Sales.

As principais sugestões para melhoria das praças foram: a colocação de plantas ornamentais e grama nos canteiros, melhoria da iluminação, pois muitos pontos de luz estão sem funcionar. Na Praça João Luís Ferreira, devido a ações de vandalismo, muitas lâmpadas foram quebradas e na Praça Landri Sales ocorre falta de manutenção, com muitas lâmpadas queimadas. Ainda, foi sugerida a possibilidade de se ter maior segurança, para evitar os roubos e vigilância para evitar o vandalismo, para com os mobiliários e equipamentos urbanos, e redução da poluição sonora, provocada pelos carros de som e pelos comerciantes informais. Na Praça João Luís Ferreira, foi sugerida a retirada dos comerciantes informais e na Praça Landri Sales, por ter atividades ativas, foi sugerida a colocação de playground.

\section{CONSIDERAÇÕES FINAIS}

As praças João Luís Ferreira e Landri Sales apresentam arborização com agrupamentos heterogêneos, com espécies diferentes, sendo o oiti (Licania tomentosa), a figueira (Ficus microcarpa), a canafístula (Cassia grandis L.F.), flamboyant (Delonix regia (Bojer ex Hook.) Raf.) e pau ferro (Caesalpina ferrea Mart. ex Tul. var. férrea), as árvores que têm presença marcante, principalmente pela sombra que favorece a permanência neste espaço.

As médias de temperatura das praças João Luís Ferreira e da Praça Landri Sales, em ambiente com vegetação (CV) e sem vegetação (SV), são semelhantes nos horários de 9 h00 e de $21 \mathrm{~h} 00$. A Praça Landri Sales apresenta valor da temperatura superior ao da Praça João Luis Ferreira às 15h00, em ambiente com vegetação, e neste horário sem vegetação não há diferença.

A umidade relativa do ar da Praça João Luís Ferreira é superior à da Praça Landri Sales, independente do local da medição (com ou sem vegetação), ocorrendo o maior valor da umidade às $9 \mathrm{~h} 00$ seguido das $21 \mathrm{~h} 00$ e $15 \mathrm{~h} 00$.

Os usuários acham as praças muito importantes para a cidade, sendo a vegetação o ponto de destaque, devido à sombra e às temperaturas mais baixas, que proporcionam nestes espaços.

As praças estudadas apresentam funções relevantes, tanto como ponto de referência para a cidade e como lugar de encontro. Geralmente, os usuários escolhem o local de permanência devido à sombra das árvores, seguido pela proximidade com o entorno (comércio, instituição bancária, escola, ponto de ônibus, etc.). A vegetação e as pessoas são os aspectos que chamam mais atenção dos usuários.

\section{REFERÊNCIA BIBLIOGRÁFICA}

ALMEIDA JÚNIOR, N. L. de. Estudo de clima urbano: uma proposta metodológica, 2004, 109 p. Dissertação (Mestrado em Física e Meio Ambiente). Cuiabá- MT: Universidade Federal de Mato Grosso, 2005.

AYOADE, J. O. Introdução à climatologia para os trópicos. Rio de Janeiro: Bertrand Brasil, 2001.

CASTELO BRANCO, A. E. Urbanização e clima em Teresina. Cadernos de Teresina. Teresina: Fundação Cultural Monsenhor Chaves, n. 35, p. 10-15, mar. 2003.

CAVAlCANTI, G. S. A Praça Landri Sales. Jornal do Piauí, Teresina, 1958, p. 7.

DE ANGELIS, B. L. D.; CASTRO, R. M. de; DE ANGELIS NETO, G. Metodologia para levantamento, diagnóstico e avaliação de praças no Brasil. Engenharia civil UM., Guimarães - Portugal, v. 20, n. 1, p. 57-70, 2004. 
DUARTE, D. H. S.; SERRA, G. G. Padrões de ocupação do solo e microclimas urbanos na região de clima tropical continental brasileira: correlações e proposta de um indicador. Ambiente Construído. Porto Alegre, v. 3, n. 2, p. 7-20, jan./jun. 2003.

FARIA, J. R. G. de; MENDES, J. F. G. Sobre o uso e ocupação do solo urbano e a temperatura do ar. Ambiente Construído. Porto Alegre, v.4, n.3, p7-17, jul./ set. 2004.

FONTES, M. S. G. de C. et al. Qualidade dos principais espaços públicos de Bauru-SP. In: Encontro Nacional de Conforto no Ambiente Construído, 7, Encontro Latino- Americano sobre conforto no ambiente Construído, 4, 2005, Maceió. Anais... Maceió, p. 697-705, 2005.

GARTLAND, L. Ilhas de calor: como mitigar zonas de calor em áreas urbanas. São Paulo: Oficina de Textos, 2010.

GOMES, M. A. S; SOARES, B. R. A vegetação nos centros urbanos: considerações sobre os espaços verdes em cidades médias brasileiras. Estudos Geográficos. Rio Claro: IGCE/UNESP, v. 1, n. 1, p. 19-26, 2003.

IBGE - Instituto Brasileiro de Geografia. Cidades. Disponível em: <http://www.ibge.gov.br/cidadesat/ topwindow.htm?1 >. Acesso em: 06 ago. 2011.

LEITÃO, L. (Org.). As praças que a gente tem, as praças que a gente quer: manual de procedimentos para intervenção em praças. Recife: Secretaria de Planejamento, Urbanismo e Meio Ambiente, 2002.

LIMA NETO, E. M. de. et al. Análise das áreas verdes das praças do bairro centro e principais avenidas da cidade de Aracaju - SE. Revista da Sociedade Brasileira de Arborização Urbana, v. 2, p. 17-33, 2007.

LORENZI, H. Árvores brasileiras: manual de identificação e cultivo de plantas arbóreas do Brasil. São Paulo: Instituto Plantarum, v. 1, 2002.

MASCARÓ, Lúcia Elvira Alicia Raffo de; MASCARÓ, Juan Luis. Vegetação urbana. Porto Alegre: L. Mascaró, J. Mascaró, 2002.

MASCARÓ, L. R. de. Ambiência urbana. Porto Alegre: Sagra: DC Luzzatto, 1996.

MENDONÇA, R. S. R de; ASSIS, E. S. de. Conforto térmico urbano: estudo de caso do bairro Floresta de Belo Horizonte, MG. Ambiente Construído. Porto Alegre, v. 3, n. 3, p. 45-63, jul./set., 2003.

MILLS, G. Luke Howard and the climate of London. Weather, v. 63, n. 4, Abril, 2008.

OLIVEIRA, E. Z. de. Percepção ambiental X arborização urbana: dos usuários da Avenida Afonso Pena entre as Ruas Calógeras a Ceará em Campo Grande - MS. REPAMS - Associação de RPPNs do Mato Grosso do Sul, p. 1-23, 2005. Disponível em: <http://www.repams.org.br/downloads/ARTIGO\%20DO\%20 MESTRADO.pdf $>$. Acesso em: 16 set. 2008.

OLIVEIRA, L. A. de; MASCARÓ, J. J. Análise da qualidade d vida sob a ótica dos espaços públicos de lazer. Ambiente Construído. Porto Alegre, v, 7, n. 2, p. 59-69, abr.jun. 2007.

PAULA, R. Z. R. de; LABAKI, L. C. A vegetação e o conforto térmico do ambiente construído: um estudo sobre a avaliação de conforto. In: ENCONTRO NACIONAL SOBRE CONFORTO NO AMBIENTE CONSTRUIIDO 8.,e ENCONTRO LATINOAMERICANO SOBRE CONFORTO NO AMBIENTE CONSTRUÍDO, 4., Maceió, Anais....,Maceió: ANTAC, p. 1424 - 1430, 2005.

PIVETTA, K. F. L.; SILVA FILHO, D. F. da. Arborização urbana. Jaboticabal: UNESP/FCAV/FUNEP, 2002 (Boletim Acadêmico).

RHEINGANTZ, P. A. Uma pequena digressão sobre conforto ambiental e qualidade de vida nos centros urbanos. Ciência \& Ambiente. Santa Maria: UFM, v. 1, n. 1, p. 35-58, jan./jun., 2001.

ROMERO, M. A. A arquitetura bioclimática do espaço público. Brasília: Editora Universidade de Brasília, 2001.

SPIRN, A. W. O jardim de granito: a natureza no desenho da cidade. Trad. de Paulo Pellegrino. São Paulo: Ed. Universidade de São Paulo, 1995.

THROSSON, S. et al. Thermal Comfort and Outdoor Activity in Japanese Urban Public Places. Environment and Behavior, v. 39, n. 45 p. 660- 684, 2007. 
VASCONCELLOS, V. M. N. de; REIS-ALVES, L. A. dos; CORBELLA, O. D. Praça Edmundo Bittencourt - Copacabana - Rio de Janeiro - a influência da morfologia urbana no microclima de uma praça em cidade tropical quente e úmida. In: ENCONTRO NACIONAL DE TECNOLOGIA DO AMBIENTE CONSTRUÍDO, 7, ENCONTRO LATINO- AMERICANO SOBRE CONFORTO NO AMBIENTE CONSTRUÍDO, 4, 2005, Maceió. Anais... Maceió, p. 2.136-2.145, 2005.

Trabalho enviado em dezembro de 2012 Trabalho aceito em janeiro de 2012 